\title{
Resource availability and meiofauna in sediment of tropical seagrass beds: Local versus global trends
}

\author{
Marleen De Troch *, Dirk Van Gansbeke, Magda Vincx \\ Ghent University, Biology Department, Marine Biology Section, Krijgslaan 281-S8, B-9000 Gent, Belgium
}

Received 7 January 2005; received in revised form 20 May 2005; accepted 26 May 2005

\begin{abstract}
Characterisation of productivity-diversity relationships forms an essential step towards a better understanding of biodiversity. In terrestrial systems this is a topical subject and most studies reported a hump-shaped relationship. For marine systems, however, the number of studies dedicated to this is low despite the high interest in this productivity-diversity relationship.

The present study reports on meiofauna density/diversity patterns in relation to resource availability as an indicator for the productivity of the ecosystem. Standardised meiofauna samples were collected in tropical seagrass beds from three localities (Kenya, Mexico, the Philippines) in order to contrast local patterns with a more global scale. Although these sites were physically comparable, a range of resource availabilities was found. These differences between localities were mainly due to different tidal regimes and related input of organic matter. At all sites a significant positive effect of resource increase on meiofauna densities was found. This positive effect was less clear for meiofauna diversity. Highest density and diversity levels were reported for the Kenyan site and this is probably linked to a high tidal range. Pooling all localities together resulted in a significant positive linear relationship between resource availability and meiofauna density/diversity. Caution should be taken when choosing resource indicators. Chlorophyll $a$ concentrations, for example, resulted in a positive density-productivity

\footnotetext{
* Corresponding author. Fax: +3292648598.

E-mail addresses: marleen.detroch@UGent.be (M. De Troch), dirk.vangansbeke@UGent.be (D. Van Gansbeke), magda.vincx@UGent.be (M. Vincx).
} 
relationship while organic carbon content, an indicator for more refractory material, showed a negative relationship. In all cases, no hump-shaped relationship could be found suggesting that each ecosystem and each group of organisms may show a particular productivity-diversity/density relationship.

(C) 2005 Elsevier Ltd. All rights reserved.

Keywords: Meiofauna; Tropical; Seagrass; Sediments; Resources; Biodiversity

\section{Introduction}

The relationship of primary productivity and species diversity on a regional scale is not straightforward (e.g., Mittelbach et al., 2001; Rosenzweig \& Abramsky, 1993) although unravelling the mechanisms driving these relationships is of fundamental importance for a better understanding of determinants of biodiversity (Huston, 1994; Mittelbach et al., 2001). Despite the attention for this topic, considerable controversy remains concerning the general shape of this relationship, what organisms fit particular models, and what mechanisms produce the patterns (Abrams, 1995; Waide et al., 1999).

Evidence for a hump-shaped relationship is accumulating: as productivity rises, first diversity increases, then it declines (for overview see Mittelbach et al., 2001). Tilman (1982) developed a theory that predicts this and he suggested that various plant data would fit it. Later on, it was illustrated for other organisms, e.g., desert rodents (Abramsky \& Rosenzweig, 1984) and bacteria (Kassen, Buckling, Bell, \& Ralney, 2000). More recently, several authors have documented other forms of the productivity-diversity relationship (e.g., Waide et al., 1999; see Mittelbach et al., 2001 for review). Worm and Duffy (2003) suggested that biodiversity-productivity relationships are often bi-directional, such that changes in biodiversity can be both cause and consequence of changes in productivity.

However, these relationships rest on controversial surrogate variables of unknown ability to stand in for productivity. Productivity is strictly defined as the rate at which energy flows through an ecosystem. But in all research cited, ecologists have used an index of productivity which is linked to resource supply (Worm, Lotze, Hillebrand, \& Sommer, 2002).

In addition, the productivity-biodiversity relationship is known to be scale-dependent (Chase \& Leibold, 2002; Wright, Currie, \& Maurer, 1993). At a local scale, the relationship may follow the expected hump-shaped curve, whereas at a regional scale the relationship is often positively linear (Chase \& Leibold, 2002; Wright et al., 1993).

While these relationships are being studied in much detail for terrestrial systems, the knowledge of such patterns in aquatic systems is limited. In the latter ones, the supply of resources is often governed by depth as it determines the availability of light for photosynthesis (e.g., Smith, 1978). Rex (1981) showed that diversity of many bottom-dwelling marine taxa (e.g., Gastropoda, Polychaeta, Protobrancha, Cumacea) follows a hump-shaped pattern with productivity. In his overview, 
Mittelbach et al. (2001) concluded that hump-shaped relationships were particularly common in aquatic systems.

Although reported as mesotrophic in the nutrient control model of Birkeland (1977, 1987, 1988a, 1988b), seagrass beds are known as resource-rich systems in tropical regions. In addition to the carbon of the plants themselves, seagrasses are typically covered by a prominent biofilm that consists mainly of microalgae, bacteria, etc. (e.g., Decho, 2000; Moncreiff \& Sullivan, 2001; Pollard \& Kogure, 1993). Due in large part to the productivity of these epiphytes, the primary productivity of seagrass beds is generally several times higher than that of adjacent unvegetated habitats (Moncreiff, Sullivan, \& Daehnick, 1992). In addition, seagrass beds get carbon input from nearby coastal systems such as mangrove forests (e.g., Bouillon, Moens, \& Dehairs, 2004). Several studies aimed to study the origin of carbon in these systems (e.g., Fleming, Lin, \& Sternberg, 1990; Holmer \& Bachmann Olsen, 2002; Marguillier, van der Velde, Dehairs, Hemminga, \& Rajagopal, 1997) rather than to unravel the effects of total resource availability on consumers.

Based on field experiments, Edgar (1999) found that invertebrate communities in seagrass beds are primarily structured by food availability, particularly in the form of seagrass debris for epifauna and fine organic particles for infaunal meiofauna (nematodes), and show little direct dependence on structural characteristics of seagrass beds. Macrofaunal and meiofaunal organisms largely consume algae, and associated protists and bacteria, and hence are secondary producers reliant directly and indirectly on primary production. It is generally expected that the diversity of an entire trophic level should respond to a change in productivity (Leibold, 1999; Rosenzweig, 1995).

The present case study aimed to test the dependence of meiofauna on resource availability. We hypothesize that a local increase in resources (mainly food) will promote meiofauna densities. Secondly, we question how resource change would have an impact on meiofauna diversity at higher taxon level. In view of the scale-dependent productivity-biodiversity relationship suggested by Chase and Leibold (2002), local (within a site) versus global patterns (between sites) were included. Therefore, three structurally comparable seagrass beds world-wide (Kenya, Mexico, the Philippines) were selected in order to test whether a positive effect of organic matter on meiofauna is a general rule. These sites had very similar physical characteristics but represented a range of resource availabilities (see characterisation of sites).

\section{Material and methods}

\subsection{Sampling sites}

Three sampling sites were included in the present study: Gazi Bay (Kenya, $4^{\circ} 22^{\prime} \mathrm{S}$ and $39^{\circ} 30^{\prime} \mathrm{E}$; sampling between $10 / 7 / 96$ and 7/8/96), Punta Allen (Mexico, $19^{\circ} 47^{\prime} \mathrm{N}$ and $87^{\circ} 28^{\prime} \mathrm{W}$; sampling between $10 / 7 / 97$ and 7/8/97) and Pujada Bay (the Philippines, $6^{\circ} 56^{\prime} \mathrm{N}$ and $126^{\circ} 16^{\prime} \mathrm{E}$; sampling between $24 / 5 / 98$ and $23 / 6 / 98$ ) (Fig. 1). The selection of these sampling sites was based on the circumtropical distribution of 


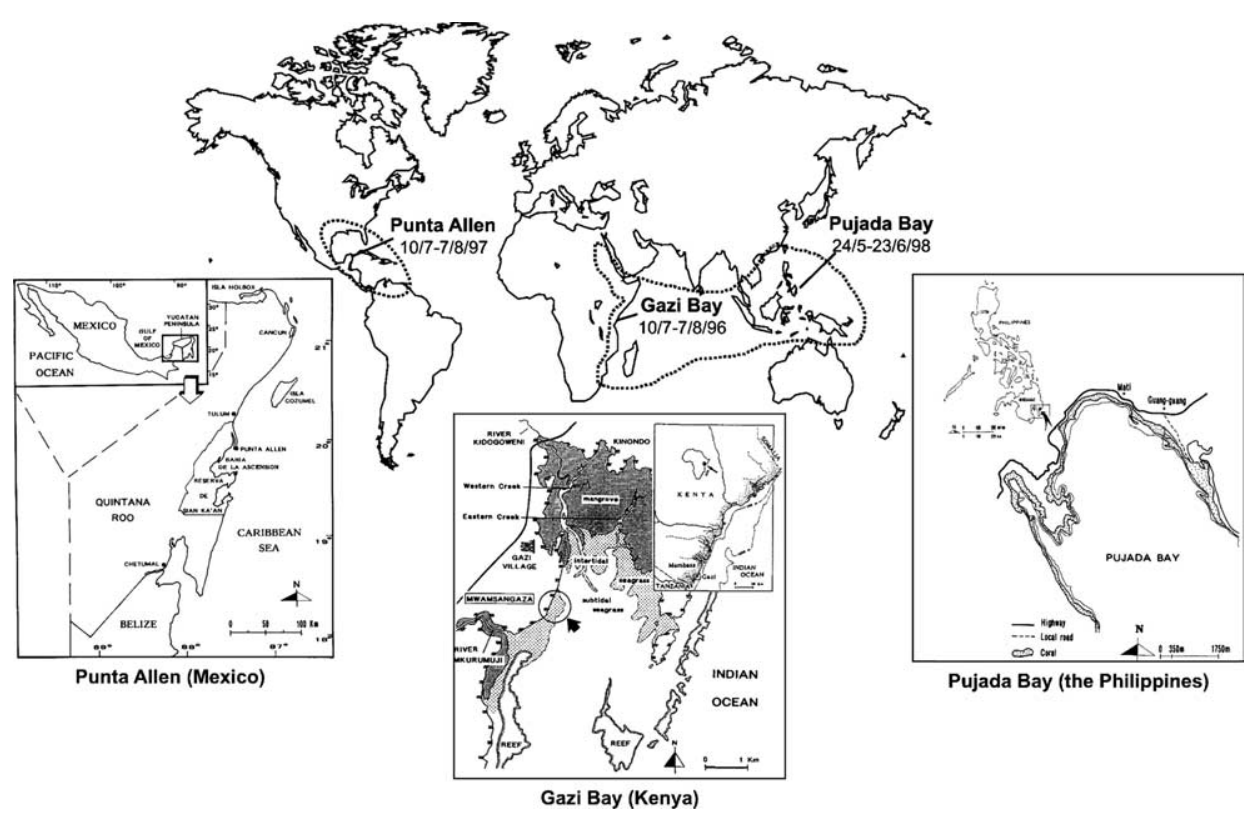

Fig. 1. Location of the three sampling sites on a global and local scale. Sampling period is indicated for each site. Sampling sites are located within the distribution region of the seagrass Thalassia association (Brazier, 1975) (indicated by the dotted line).

seagrass species of the Thalassia association (including the seagrass genera Syringodium, Halodule and Thalassia) as defined by Brazier (1975) (Fig. 1). Furthermore, these regions were listed among the 25 biodiversity global hotspots of the world based on species endemisms and degree of threat (Myers, Mittermeier, Mittermeier, da Fonseca, \& Kent, 2000).

\subsection{Benthic meiofauna}

Benthic meiofauna was sampled using PVC meiocores of $3.6 \mathrm{~cm}$ inner diameter (surface of $10 \mathrm{~cm}^{2}$ ). Meiocores were randomly inserted into the sediment down to a depth of $10 \mathrm{~cm}$ and were vertically subdivided on site into the following depth horizons: $0-1 \mathrm{~cm}, 1-2 \mathrm{~cm}, 2-3 \mathrm{~cm}, 3-4 \mathrm{~cm}, 4-5 \mathrm{~cm}$ and 5-10 cm, using a standard Hagge corer for vertical sectioning (Fleeger, Thistle, \& Thiel, 1988). All samples were obtained by snorkelling under a water cover between 1 and $2 \mathrm{~m}$. Samples were preserved with warm $\left(60^{\circ} \mathrm{C}\right)$ buffered formaldehyde in freshwater to a final concentration of $4 \%$ (Vincx, 1996).

In each sampling site, triplicate samples were taken at random within zones of 3 seagrass species (of the genera Syringodium, Halodule and Thalassia). Within each zone, two $5 \times 5 \mathrm{~m}$ quadrats were selected, situated on two transects and separated approximately $500 \mathrm{~m}$ from each other. Both transects represent a series of samples along a gradient of seagrass species and were perpendicular to the beach as the seagrass zones were parallel to the beach. 
Taking into account the 6 depth horizons, this sampling design yielded a total of $3 \times 2 \times 3 \times 6=108$ samples per site (seagrass species $\times$ qaudrats on transect $\times$ replicates $\times$ depth horizons). In order to report major trends, meiofauna density (ind./ $10 \mathrm{~cm}^{2}$ ) and diversity (number of taxa, see further) of samples of transects and replicates were averaged per seagrass species, resulting in a total of 18 samples per site (6 depth horizons $\times 3$ seagrass species).

In the laboratory, samples were rinsed with a jet of freshwater over a $1 \mathrm{~mm}$ sieve, decanted ten times over a 38- $\mu \mathrm{m}$ mesh sieve, centrifuged three times with Ludox HS40 (specific density 1.18), and finally stained with Rose Bengal. Meiofauna was sorted and enumerated at higher taxon level using a Wild M5 binocular. Meiofauna taxa identification was based on Higgins and Thiel (1988). Meiofauna groups collected were: Cnidaria, Turbellaria, Gnathostomulida, Gastrotricha, Nematoda, Rotifera, Kinorhyncha, Loricifera, Priapulida, Gastropoda, Bivalvia, Polychaeta, Oligochaeta, Sipunculida, Tardigrada, Halacarida, Ostracoda, Cephalocarida, Copepoda, Amphipoda, Cumacea, Isopoda, 'nauplii' and insect larvae.

\subsection{Resources availability}

Per quadrat $(5 \times 5 \mathrm{~m})$ two sediment samples for resource analysis were taken with a core of $6.2 \mathrm{~cm}$ inner diameter, and subdivided into 6 depth slices as explained for the meiofauna. These samples were immediately stored frozen until further analysis. Part of the sediment was dried for $4 \mathrm{~h}$ at $110^{\circ} \mathrm{C}$ and used for organic matter analysis (total organic matter, \% \%OM) by measuring weight loss after ignition at $550{ }^{\circ} \mathrm{C}$ for $2 \mathrm{~h}$. \%TOM was used as a broad measure for the more refractory detritus, i.e., low quality food that refers to older material from, e.g., mangroves, decomposed seagrass leaves.

Per quadrat, triplicate small $(\sim 1 \mathrm{ml})$ sediment samples from the different depth layers were taken with a syringe (with the lower end cut-off) and stored frozen. These samples served for the chromatographic analysis of the phytopigment chlorophyll $a$. Pigments were extracted in $90 \%$ acetone at $4{ }^{\circ} \mathrm{C}$ in the dark and separated by reverse phase liquid chromatography on a Gilson C-18 HPLC-chain (fluorometrical and spectrophotometrical detection) according to a modified protocol of Mantoura and Llewellyn (1983). Chlorophyll $a$ concentrations were used as a measure for microalgae and indicate the presence of 'fresh' detritus. As chlorophyll $a$ is an indication for labile phytoplankton, it is quickly decomposed and suggests an unstable food availability for meiofauna (e.g., Decho \& Fleeger, 1988; Greiser \& Faubel, 1988; Tietjen, 1968). Taking into account the quality of the material rather than the quantity of the available resources, the fraction chla/\%TOM was used as a measure for the pool of consumable organic matter.

\subsection{Statistics}

Linear regressions (best fitting linear curves) between meiofauna density/diversity and resource levels were analysed with the STATISTICA software package (StatSoft, 1995). Differences in meiofauna density and diversity between sampling sites 
were tested with one-way ANOVA after a Cochran's $C$-test to check the assumption of homoscedasticity. A post hoc Tukey HSD test for equal $n$ was used for pairwise comparison between sites (Zar, 1996).

\section{Results}

\subsection{Available resources in relation to meiofauna density and diversity: local patterns}

\subsubsection{Characterisation of each sampling site}

In each sampling site a highly significant positive correlation $(p<0.001)$ was found between the chla/\%TOM fraction and meiofauna density (Fig. 2). The correlation between meiofauna diversity and chla/\%TOM was never significant (correlation line not shown).

In Kenya the chla/\%TOM fraction varied between 0.12 and 1.03 . Average ( \pm standard error) meiofauna density corresponding to these food conditions was $732 \pm 150$ ind. $/ 10 \mathrm{~cm}^{2}$. An average ( \pm standard error) number of $15.1 \pm 0.7$ taxa was counted.

In the Mexican samples, however, this fraction was only half of the Kenyan samples with values between 0.06 and 0.51 . Corresponding lower meiofauna density (on average $254 \pm 35$ ind./10 $\left.\mathrm{cm}^{2}\right)$ and lower average taxon diversity (11.5 \pm 0.5 taxa) were recorded in Punta Allen (Mexico).

Moreover, the fraction available food for meiofauna was even less in Mati (the Philippines), ranging between only 0.002 and 0.102 of the total amount of organic matter available (\%TOM). In this site, meiofauna density was on average $285 \pm 33$ ind. $/ 10 \mathrm{~cm}^{2}$ and diversity dropped down to $8.2 \pm 0.4$ taxa.

The higher values of the fraction chlorophyll $a / \%$ TOM in the Kenyan sampling site (Fig. 2, top) were linked to a wider range of organic matter i.e., ranging from 1.5 to $4.9 \%$ TOM (Fig. 3(a)). The lowest values in this range (on average $1.7 \pm 0.1 \%$ TOM over all depth layers) were found at the high intertidal level where samples were collected near Halodule wrightii. Thalassia hemprichii was characterised by an average of $3.6 \pm 0.2 \%$ TOM. The highest values were noted for the sediment samples collected near Syringodium isoetifolium ( $4.3 \pm 0.2 \%$ TOM). In the Mexican seagrass bed (Fig. 3(b)) \%TOM varied in a narrow range between 3.9 and 4.9, whereas \%TOM ranged between 3.2 and 4.2 in the Philippines (Fig. 3(c)).

In addition to these different \%TOM concentrations, the geographic locations were characterised by highly significant differences $\left(F_{(2,51)}=8.6, p<0.001\right.$, oneway ANOVA) in meiofauna density. The highest numbers of meiofauna taxa $\left(15 \pm 0.7\right.$ taxa) and meiofauna density $\left(730 \pm 150\right.$ ind. $\left./ 10 \mathrm{~cm}^{2}\right)$ were noted in the Kenyan site (Fig. 3(a,c)). A post hoc Tukey HSD test for equal $\mathrm{n}$ indicated no significant differences in meiofauna density between the Mexican $\left(255 \pm 35\right.$ ind./10 $\left.\mathrm{cm}^{2}\right)$ (Fig. 3(b,e)) and the Philippines site $\left(283 \pm 33\right.$ ind./10 $\left.\mathrm{cm}^{2}\right)$ (Fig. 3(c,f)), while both sites were significantly different from the Kenyan samples (Tukey HSD, $p<0.01$ ).

Secondly, chlorophyll $a$ concentrations (Fig. 3(d)-(f)) were highest in the Kenyan samples (Fig. 3(d)) ranging from 0.5 to $4.4 \mu \mathrm{g} / \mathrm{g}$. There was a significant positive correlation between chlorophyll $a$ level and meiofauna density $\left(p<0.01, r^{2}=0.44\right.$, 

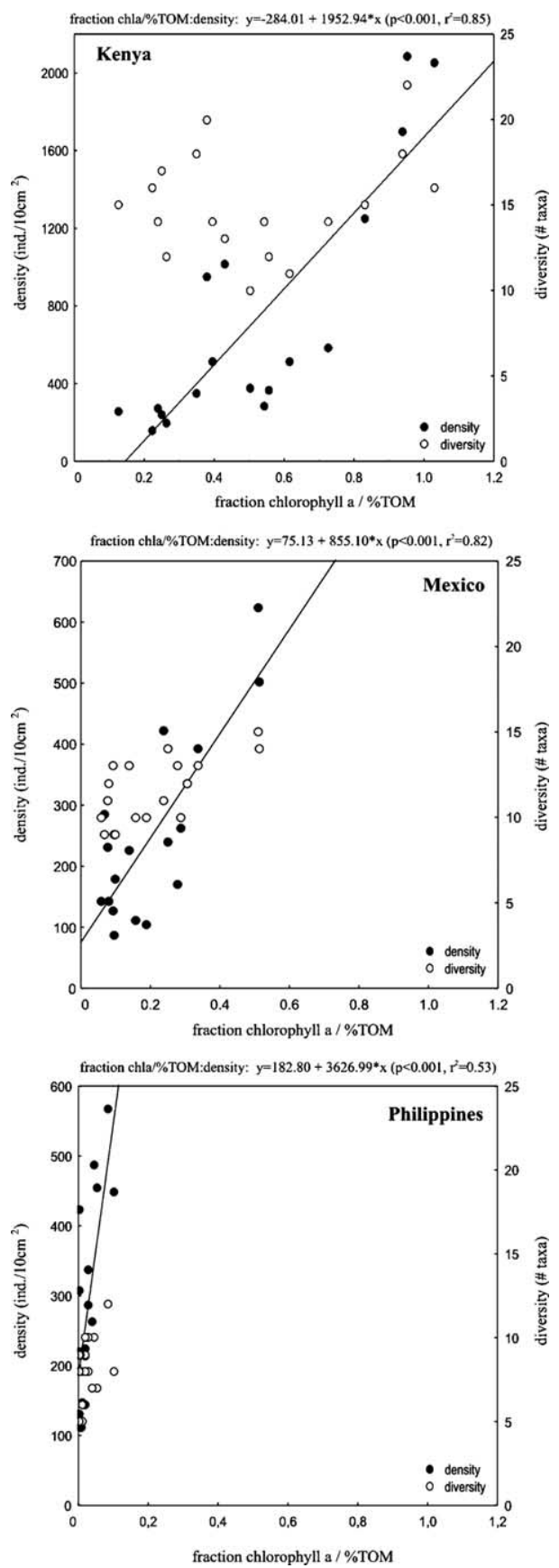

Fig. 2. Meiofauna characteristics (density and diversity) versus available resources expressed as fraction chlorophyll $a$ of $\%$ total organic matter (\%TOM) in each sampling site. Meiofauna densities are indicated by filled circles and plotted along the left $y$-axis; meiofauna diversities are indicated by open circles and plotted along the right $y$-axis. Regression equation is given above each figure. 

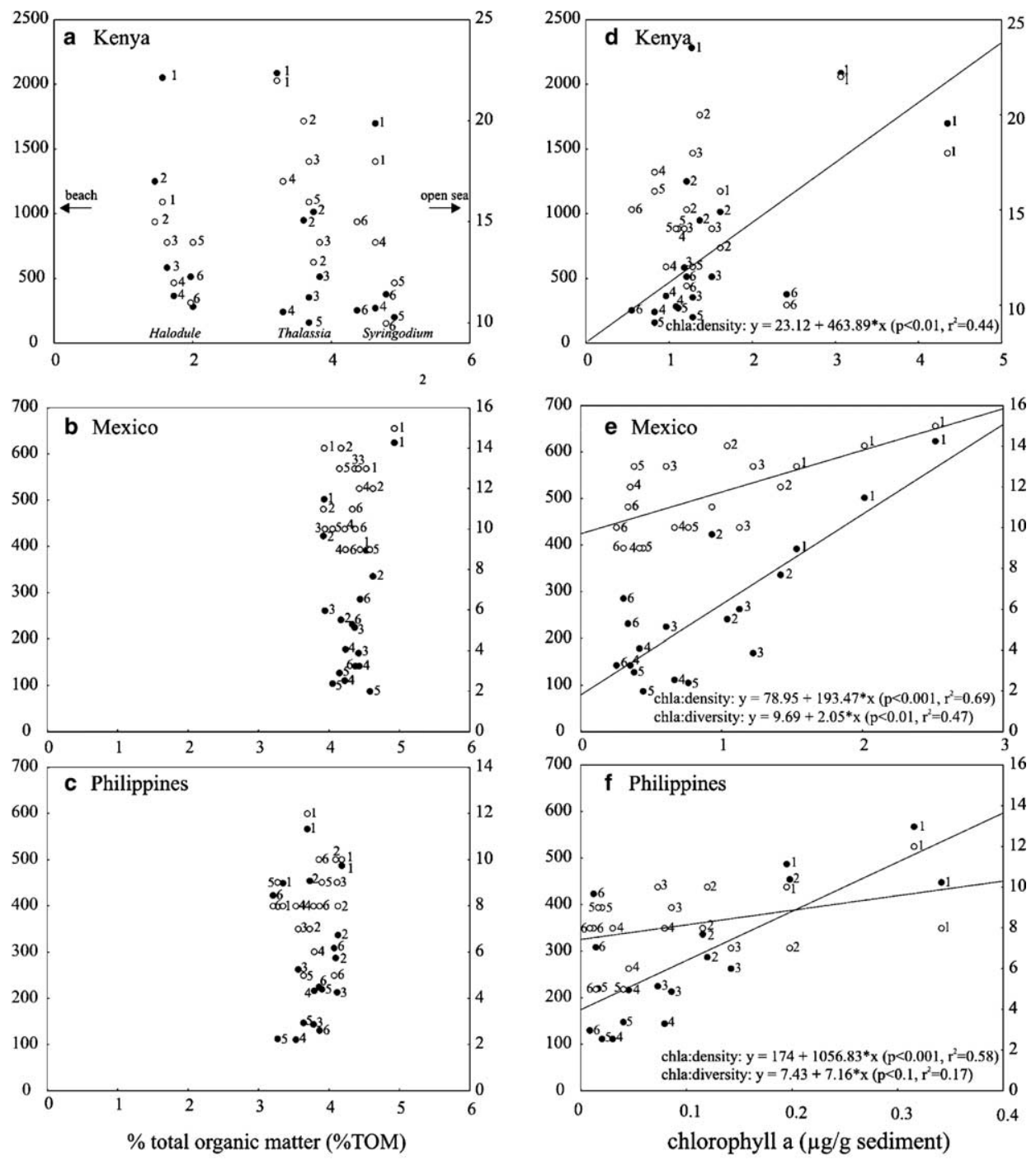

- density (ind./10 $\mathrm{cm}^{2}$, left axis)
o diversity (\#taxa, right axis)

Fig. 3. Percentage total organic matter (\%TOM) (a-c) and chlorophyll $a$ concentration $(\mathrm{d}-\mathrm{f})$ versus meiofauna density (left axis) and diversity (right axis) for each sampling site. Meiofauna densities are indicated by filled circles and plotted along the left $y$-axis; meiofauna diversities are indicated by open circles and plotted along the right $y$-axis. Depth horizons were indicated as $1(0-1 \mathrm{~cm}), 2(1-2 \mathrm{~cm}), 3(2-$ $3 \mathrm{~cm}), 4(3-4 \mathrm{~cm}), 5(4-5 \mathrm{~cm})$ and $6(5-10 \mathrm{~cm})$. In case of significant regression, the regression equation is given at the bottom of each figure.

Fig. 3(d)) but not between chlorophyll $a$ and meiofauna diversity ( $p=0.2$ ). In the two other sites (Fig. 3(e,f)), chlorophyll $a$ concentrations were much lower and a highly significant $(p<0.001)$ positive correlation was found with meiofauna density. 

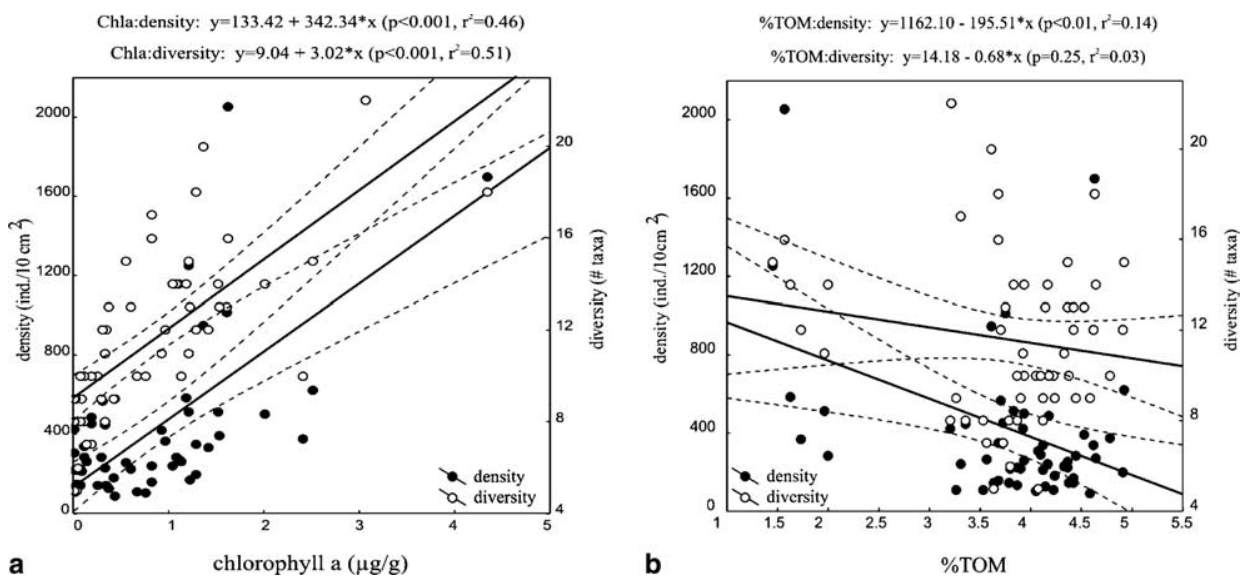

Fig. 4. Global trend of meiofauna characteristics (density and diversity) versus available resources expressed as (a) primary production in terms of chlorophyll $a$ ( $\mu \mathrm{g} / \mathrm{g}$ sediment) and (b) $\%$ total organic matter $(\%$ TOM) from three circumtropical seagrass sites. Meiofauna densities are indicated by filled circles and plotted along the left $y$-axis; meiofauna diversities are indicated by open circles and plotted along the right $y$-axis. Regression equation is given above each figure. Dotted lines indicate $95 \%$ confidence bands.

Meiofauna diversity was also significantly positively related to the fresh available primary production (chlorophyll $a$ ) but the correlation was much weaker with $p<0.01$ and $p<0.1 ; r^{2}=0.47$ and $r^{2}=0.17$ at the Mexican and the Philippines sites, respectively. At all locations, the highest values of chlorophyll $a$ were concentrated in the top sediment layers.

\subsection{Available resources in relation to meiofauna density and diversity: a global trend?}

When pooling meiofauna data for the three sampling sites, a highly significant positive correlation $(p<0.001)$ was found between chlorophyll $a$ levels and meiofauna density $\left(r^{2}=0.46\right)$ and diversity $\left(r^{2}=0.51\right)$ (Fig. 4(a)).

However, the relation between benthic meiofauna density/diversity and \%TOM (Fig. 4(b)) was much weaker with $r^{2}=0.14$ (density) and $r^{2}=0.03$ (diversity). The correlation was even not significant for diversity $(p=0.25)$ but was highly significant for density $(p<0.01)$. In contrast to the positive correlation with chlorophyll $a$, the slope was negative for both density and diversity as an increase in organic matter (\% TOM) coincided with a lower meiofauna density and diversity.

\section{Discussion}

In spite of the increasing interest for productivity-diversity relationships, the major source for different outcome of these studies is the surrogate for productivity that was used. Typically, ecologists try to find an index of productivity which is linked to resource supply (Worm et al., 2002). Moreover, this index is often selected depending 
on the group of organisms that was studied. As a result of all this, the described relationships rest on controversial surrogate variables of unknown ability to stand in for productivity. In the present study, we used mainly indicators of primary production (chlorophyll $a, \%$ total organic matter) as surrogates for productivity in tropical seagrass beds. Clearly, this selection was related to the group of organisms that was studied. Meiofaunal organisms are metazoans between $38 \mu \mathrm{m}$ and $1 \mathrm{~mm}$ and are known as important consumers of primary production (e.g., Danovaro, Gambi, \& Mirto, 2002; Gee, 1989).

In addition, this case study aimed to document productivity-diversity relationships at the higher taxon level while most previous studies reported on the species level (e.g., Abramsky \& Rosenzweig, 1984; Rex, 1981). Our rationale for studying taxon rather than species diversity are: (1) the taxonomic limitations of different meiofaunal groups, especially in tropical ecosystems (e.g., about $70 \%$ of meiofaunal harpacticoid copepods in these regions are new to science, De Troch, 2001); (2) food preferences and strategies within a specific meiofauna group are far from known. Species-specific food preferences are only documented for a few nematode (e.g., Moens, Verbeeck, de Maeyer, Swings, \& Vincx, 1999; Ólafsson, Modig, \& van de Bund, 1999) and copepod species (e.g., Buffan-Dubau \& Carman, 2000; De Troch, Steinarsdóttir, Chepurnov, \& Ólafsson, 2005; Pace \& Carman, 1996) and may imply that certain levels of productivity will be used in different ways, i.e., less or more intensive so certain segments of the productivity range will be characterised by lower or higher species diversity. The use of higher taxa may skew the resolution of the diversity trends, however, it is hard to say whether this would consequently result in a hump-shaped relationship between productivity and diversity. For this, smallscale experiments with a range of available resources and number of species to harbour would be a step forward. However, field or laboratory experiments would only resolve some of the questions as historical information and evolution would be neglected. Moreover, the naturally available range of resource is of major importance in this context.

In terms of resource availability for meiofauna, the sampling sites covered a wide range, although they were structurally comparable as similar seagrass species belonging to the so-called Thalassia association (Brazier, 1975) occurred. We found that chlorophyll $a / \%$ TOM ratio ranged from 0.002 to 1.03 which spans almost three orders of magnitude. In view of their high production, seagrass beds have a high nutrient demand (Holmer, Andersen, Holmboe, Kristensen, \& Thongtham, 2001). As nutrient concentrations in seawater are typically low in tropical seas, this nutrient demand of seagrasses appears to be met by efficient systems of nutrient trapping, uptake and recycling (Erftemeijer \& Middelburg, 1995; Hemminga \& Nieuwenhuize, 1991). Nutrient recycling can be accomplished through rapid in situ decomposition of seagrass-derived organic matter within the seagrass beds, although the rate of decomposition of detritus may be constrained by nutrient limitation as the decomposing plant tissues have lower nutrient contents than the decomposing bacteria (Fenchel, King, \& Blackhurn, 1998).

Another important source of detritus in seagrass ecosystems results from exported mangrove litter (Alongi, Boto, \& Tirendi, 1989; Hemminga et al., 1994), but yet it is 
not clear whether seagrass beds are net sinks or sources of dissolved inorganic and organic matter (Holmer et al., 2001). In their study on benthic processes along a mangrove-seagrass transect, Holmer et al. (2001) found a minor variation in benthic mineralisation along the transect, suggesting that the mineralizable pool of organic matter was of similar magnitude at all sites.

In the nutrient control model of Birkeland (1977, 1987, 1988a, 1988b), seagrass ecosystem rank among mesotrophic systems whereas corals are characterised by lower nutrient input (oligotrophic) and sponges occupy the other extreme end of the scale (eutrophic). From this model, we expect that an increase in primary production (mainly in the water column) would result in reduced light levels reaching the benthos and the seagrasses. Algal growth is reduced and the bottom community becomes dominated by suspension-feeding animals such as epifaunal bivalves, barnacles, massive sponges and ascidians. As such, an increase in productivity (related to the decreasing phase of the humped-shaped relationship) would inextricably lead to the disappearance of seagrass plants and associated fauna. The lack of a wide range of resources availability within seagrass beds may be a first explanation why no hump-shaped relationship could be found in the present study.

Although local variability was not included in detail (but see De Troch, Fiers, \& Vincx, 2001, 2003), our results suggest that local processes that govern each site clearly differ between sites but yet are complex. Local differences in the studied seagrass beds are primarily related to the fact that samples from different seagrass species and different depth horizons were included, resulting in a variety of niches for meiofauna. The wide range of \% TOM in Gazi Bay can be explained by the large tidal range that occurs along the Kenyan coast. Gazi Bay experiences semi-diurnal tides, with spring and neap tide ranges of 3.2 and $1.4 \mathrm{~m}$, respectively (Kitheka, 1997). At this almost meso-tidal site (tide range between 2-4 m, Davies, 1964), the lowest \%TOM was noted towards the beach suggesting a kind of dilution, 'run-off', of organic matter towards the beach. In this sense, the lowest values (Halodule wrightii) correspond to a low amount of local seagrass material. In spite of the run-off and possible loss of organic matter on the meso-tidal site (Kenya), meiofauna density and diversity were highest in the Kenyan site.

In contrast to Kenya, the two other sites are characterised by a micro-tidal (tide range $<2 \mathrm{~m}$, Davies, 1964), almost atidal, regime with little to no visible difference between low and high tide. One would expect that a low tidal movement results in a lower input of fresh material from surrounding waters (e.g., from adjacent mangroves). In addition, less phytoplankton in combination with more refractory detritus material from the autochthonous seagrass plants could be expected.

The global analysis of all sites together yielded opposite trends depending on the measure used for the available resource (i.e., chlorophyll $a$ or $\%$ TOM). This different outcome illustrates that the selection of an appropriate standard for resources availability in seagrass beds, or marine ecosystems in general, is not evident as opposite trends may emerge from it. The opposite trend of both correlations is clearly the result of a different bio-availability of organic matter in both measurements. In this sense, the fraction chlorophyll $a / \%$ TOM (Fig. 5) gives a more reliable measure, especially on a global scale. This overall figure (Fig. 5) supports a highly significant 


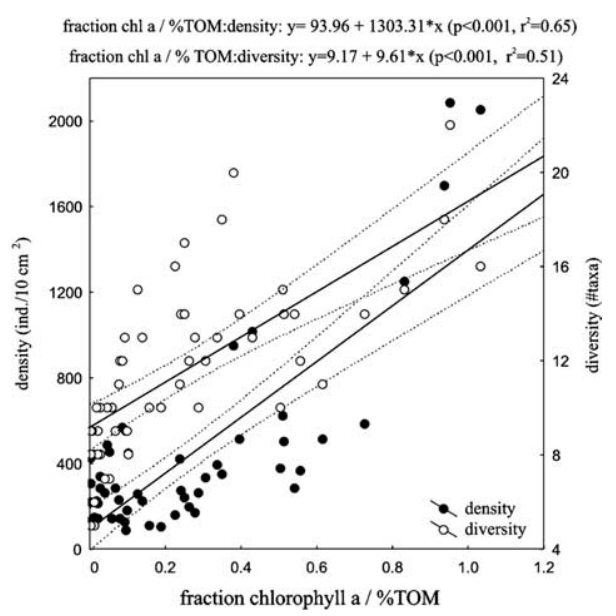

Fig. 5. Global trend of meiofauna characteristics (density and diversity) versus available resources expressed as fraction chlorophyll $a$ of $\%$ total organic matter (\%TOM). Meiofauna densities are indicated by filled circles and plotted along the left $y$-axis; meiofauna diversities are indicated by open circles and plotted along the right $y$-axis. Regression equation is given above each figure. Dotted lines indicate $95 \%$ confidence bands.

positive linear relationship between this fraction of directly accessible resources and meiofauna density and diversity in sediment of seagrass beds.

In addition, the intersite differences can also be due to the fact that we collected samples in different years, though in the same season. So, interannual variance can be considered as a possible source of variability of the data.

On both local and global scale, a linear relationship between meiofauna taxon diversity and productivity was found. Although Chase and Leibold (2002) illustrated that the productivity-diversity relationship depends on the spatial scale that is studied. They found a hump-shaped relationship on a local scale (i.e., among the ponds studied) whereas the same data analysed on a regional scale (among watersheds) were positively linear. However, Mittelbach et al. (2001) found that a hump-shaped relationship was especially common $(65 \%)$ in studies of plant diversity and in studies conducted in aquatic systems. All this suggests that the hump-shaped relationship is not as universal as expected and that each ecosytems and maybe each group of organisms may show a particular trend.

\section{Acknowledgements}

The first author acknowledges a postdoctoral fellowship from the Fund for Scientific Research (FWO-Flanders, Belgium). The samples for this study were collected during the FWO Research Program 32.0086.96. Further financial support was received from Ghent University (Belgium) (Contract BOF 98-03, 12050398) and FWO Research Program G.0199.03. The authors thank the director and the staff 
of local research centres for their logistic support and cooperation during the sampling campaigns: Kenya Marine and Fisheries Research Institute (KMFRI, Mombasa, Kenya), El Colegio de la Frontera Sur (ECOSUR, Chetumal, Mexico) and Davao Oriental State College of Technology (DOSCT, Mati, the Philippines).

Special thanks for Tom Gheskiere and Tom Moens for their valuable comments and help throughout the elaboration of this manuscript. Two anonymous reviewers gave valuable comments on the manuscript.

\section{References}

Abrams, P. A. (1995). Monotonic or unimodal diversity-productivity gradients: What does competition theory predict? Ecology 76, 2019-2027.

Abramsky, Z., \& Rosenzweig, M. L. (1984). Tilman's predicted productivity-diversity relationship shown by desert rodents. Nature, 309, 150-151.

Alongi, D. M., Boto, K. G., \& Tirendi, F. (1989). Effect of exported mangrove litter on bacterial productivity and dissolved organic carbon fluxes in adjacent tropical nearshore sediments. Marine Ecology Progress Series, 56, 133-144.

Birkeland, C. (1977). The importance of rate of biomass accumulation in early successional stages of benthic communities to the survival of coral recruits. Proceedings of the third international coral reef symposium, Miami (Vol. 1, pp. 15-21). Miami, FL: University of Miami.

Birkeland, C. (1987). Nutrient availability as a major determinant of differences among coastal hardsubstratum communities in different regions of the tropics. UNESCO Reports on Marine Science, 46, 45-97.

Birkeland, C. (1988a). Second-order ecological effects of nutrient input into coral communities. Galaxea, 7, 91-100.

Birkeland, C. (1988b). Geographic comparisons of coral-reef community processes. In Proceedings of the sixth international coral reef symposium, Townsville (Vol. 1, pp. 211-220). Townsville, Qld: Sixth International Coral Reef Symposium Executive Committee.

Bouillon, S., Moens, T., \& Dehairs, F. (2004). Carbon sources supporting benthic mineralization in mangrove and adjacent seagrass sediments (Gazi Bay, Kenya). Biogeosciences, 1, 311-333.

Brazier, M. D. (1975). An outline history of seagrass communities. Palaeontology, 18, 681-702.

Buffan-Dubau, E., \& Carman, K. R. (2000). Diel feeding behavior of meiofauna and their relationships with microalgal resources. Limnology and Oceanography, 45(2), 381-395.

Chase, J. M., \& Leibold, M. A. (2002). Spatial scale dictates the productivity-biodiversity relationship. Nature, 416, 427-430.

Danovaro, R., Gambi, C., \& Mirto, S. (2002). Meiofaunal production and energy transfer efficiency in a seagrass Posidonia oceanica bed in the western Mediterranean. Marine Ecology Progress Series, 234, 95-104.

Davies, J. L. (1964). A morphogenic approach to world shorelines. Zeitschrift für Geomorphogie, 8, $127-142$.

Decho, A. W. (2000). Microbial biofilms in intertidal systems: an overview. Continental Shelf Research, 20, $1257-1273$.

Decho, A. W., \& Fleeger, J. W. (1988). Microscale dispersion of meiobenthic copepods in response to food-resource patchiness. Journal of Experimental Marine Ecology and Biology, 118, 229-243.

De Troch, M. (2001). Ecologie van harpacticoide copepoden: structurele biodiversiteit in tropische zeegrasvelden. Ecology of harpacticoid copepods: structural biodiversity in tropical seagrass beds ( $\mathrm{p}$. 254). $\mathrm{PhD}$ dissertation, Ghent University.

De Troch, M., Fiers, F., \& Vincx, M. (2001). Alpha and beta diversity of harpacticoid copepods in a tropical seagrass bed: the relation between diversity and species' range size distribution. Marine Ecology Progress Series, 215, 225-236. 
De Troch, M., Fiers, F., \& Vincx, M. (2003). Niche segregation and habitat specialization of harpacticoid copepods in a tropical seagrass bed. Marine Biology, 142, 345-355.

De Troch, M., Steinarsdóttir, M. B., Chepurnov, V., \& Ólafsson, E. (2005). Grazing on diatoms by harpacticoid copepods: species-specific density-dependent uptake and microbial gardening. Aquatic Microbial Ecology, 39, 135-144.

Edgar, G. J. (1999). Experimental analysis of structural versus trophic importance of seagrass beds. I. Effects on macrofaunal and meiofaunal invertebrates. Vie et Milieu, 49, 239-248.

Erftemeijer, P. L. A., \& Middelburg, J. (1995). Mass balance constraints on nutrient cycling in tropical seagrass beds. Aquatic Botany, 50, 21-36.

Fenchel, T., King, G. M., \& Blackhurn, T. H. (1998). Bacterial biogeochemistry: The ecophysiology of mineral cycling. London: Academic Press.

Fleeger, J. W., Thistle, D., \& Thiel, H. (1988). Sampling equipment. In R. P. Higgins \& H. Thiel (Eds.), Introduction to the study of meiofauna (pp. 115-125). London: Smithsonian Institution Press.

Fleming, M., Lin, G., \& Sternberg, L. D. S. L. (1990). Influence of mangrove detritus in an estuarine ecosystem. Bulletin of Marine Science, 47, 663-669.

Gee, J. M. (1989). An ecological and economic review of meiofauna as food for fish. Zoological Journal of the Linnean Society, 96, 243-261.

Greiser, N., \& Faubel, A. (1988). Biotic factors. In R. P. Higgins \& H. Thiel (Eds.), Introduction to the study of meiofauna (pp. 79-114). London: Smithsonian Institution Press.

Hemminga, M. A., \& Nieuwenhuize, J. (1991). Transport, decomposition, and in situ decay of seagrass in a tropical mudflat area (Banc d'Arguin, Mauretania). Netherlands Journal of Sea Research, 27, 183-190.

Hemminga, M. A., Slim, F. J., Kazungu, J., Ganssen, G. M., Nieuwenhuize, J., \& Kruyt, N. M. (1994). Carbon outwelling from a mangrove forest with adjacent seagrass beds and coral reefs (Gazi Bay, Kenya). Marine Ecology Progress Series, 106, 291-301.

Higgins, R. P., \& Thiel, H. (1988). Introduction to the study of meiofauna. London: Smithsonian Institution Press.

Holmer, M., Andersen, F. Ø., Holmboe, N., Kristensen, E., \& Thongtham, N. (2001). Spatial and temporal variability in benthic processes along a mangrove-seagrass transect near the Bangrong Mangrove, Thailand. Wetlands Ecology and Management, 9, 141-158.

Holmer, M., \& Bachmann Olsen, A. (2002). Role of decomposition of mangrove and seagrass detritus in sediment carbon and nitrogen cycling in a tropical mangrove forest. Marine Ecology Progress Series, 230, 87-101.

Huston, M. A. (1994). Biological diversity: The coexistence of species on changing landscapes. Cambridge: Cambridge University Press.

Kassen, R., Buckling, A., Bell, G., \& Ralney, P. B. (2000). Diversity peaks at intermediate productivity in a laboratory microcosm. Nature, 406, 508-512.

Kitheka, J. U. (1997). Coastal tidally-driven circulation and the role of water exchange in the linkage between tropical coastal ecosystems. Estuarine, Coastal and Shelf Science, 45, 177-187.

Leibold, M. A. (1999). Biodiversity and nutrient enrichment in pond plankton communities. Evolutionary Ecology Research, 1, 73-95.

Mantoura, R. F. C., \& Llewellyn, C. A. (1983). The rapid determination of algal chlorophyll and carotenoid pigments and their breakdown products in natural waters by reverse-phase highperformance liquid chromatography. Analytica Chimica Acta, 151, 297-314.

Marguillier, S., van der Velde, G., Dehairs, F., Hemminga, M. A., \& Rajagopal, S. (1997). Trophic relationships in an interlinked mangrove-seagrass ecosystem as traced by $\delta^{13} \mathrm{C}$ and $\delta^{15} \mathrm{~N}$. Marine Ecology Progress Series, 151, 115-121.

Mittelbach, G. G., Steiner, C. F., Scheiner, S. M., Gross, K. L., Reynolds, H. L., Waide, R. B., et al. (2001). What is the observed relationship between species richness and productivity? Ecology, 82, 2381-2396.

Moens, T., Verbeeck, L., de Maeyer, A., Swings, J., \& Vincx, M. (1999). Selective attraction of marine bacterivorous nematodes to their bacterial food. Marine Ecology Progress Series, 176, 165-178.

Moncreiff, C. A., \& Sullivan, M. J. (2001). Trophic importance of epiphytic algae in subtropical seagrass beds: evidence from multiple stable isotope analyses. Marine Ecology Progress Series, 215, 93-106. 
Moncreiff, C. A., Sullivan, M. J., \& Daehnick, A. E. (1992). Primary production dynamics in seagrass beds of Mississippi sound: the contributions of seagrass, epiphytic algae, sand microflora, and phytoplankton. Marine Ecology Progress Series, 87, 161-171.

Myers, N., Mittermeier, R. A., Mittermeier, C. G., da Fonseca, G. A., \& Kent, J. (2000). Biodiversity hotspots for conservation priorities. Nature, 403, 853-858.

Ólafsson, E., Modig, H., \& van de Bund, W. J. (1999). Species specific uptake of radio-labelled phytodetritus by benthic meiofauna from the Baltic Sea. Marine Ecology Progress Series, 177, 63-72.

Pace, M. C., \& Carman, K. R. (1996). Interspecific differences among meiobenthic copepods in the use of microalgal food sources. Marine Ecology Progress Series, 143, 77-86.

Pollard, P. C., \& Kogure, K. (1993). The role of epiphytic and epibenthic algal productivity in a tropical seagrass, Syringodium isoetifolium (Aschers.) Dandy, community. Australian Journal of Marine and Freshwater Research, 44, 141-154.

StatSoft Inc. (1995). STATISTICA for the windows operating system. Release 5.5. Tulsa OK, USA: Statsoft, Inc.

Rex, M. A. (1981). Community structure in the deep-sea benthos. Annual Review of Ecology and Systematics, 12, 331-353.

Rosenzweig, M. L. (1995). Species diversity in space and time. Cambridge, UK: Cambridge University Press.

Rosenzweig, M. L., \& Abramsky, Z. (1993). How are diversity and productivity related? In R. E. Ricklefs \& D. Schluter (Eds.), Species diversity in ecological communities: Historical and geographical perspectives (pp. 52-65). Chicago, USA: University of Chicago Press.

Smith, K. L. Jr., (1978). Benthic community respiration in the N.M. Atlantic Ocean. Marine Biology, 47, 337-347.

Tietjen, J. H. (1968). Chlorophyll and pheo-pigments in estuarine sediments. Limnology and Oceanography, 13, 189-192.

Tilman, D. (1982). Resource competition and community structure. Princeton, NJ, USA: Princeton University Press.

Vincx, M. (1996). Meiofauna in marine and freshwater sediments. In G. S. Hall (Ed.), Methods for the examination of organismal diversity in soils and sediments (pp. 187-195). UK: CAB International Wallingfort.

Waide, R. B., Willig, M. R., Steiner, C. F., Mittelbach, G. G., Gough, L., Dodson, S. I., et al. (1999). The relationship between primary productivity and species richness. Annual Review of Ecology and Systematics, 30, 257-300.

Worm, B., \& Duffy, J. E. (2003). Biodiversity, productivity and stability in real food webs. Trends in Ecology and Evolution, 18, 628-632.

Worm, B., Lotze, H. K., Hillebrand, H., \& Sommer, U. (2002). Consumer versus resource control of species diversity and ecosystem functioning. Nature, 417, 848-851.

Wright, D. H., Currie, D. J., \& Maurer, B. A. (1993). Energy supply and patterns of species richness on local and regional scales. In R. E. Ricklefs \& D. Schluter (Eds.), Species diversity in ecological communities: historical and geographical perspectives (pp. 66-74). Chicago, USA: University of Chicago Press.

Zar, J. H. (1996). Biostatistical analysis (3rd ed.). Upper Saddle River, NJ, USA: Prentice-Hall, p. 662. 